\title{
ANALYSIS OF RESEARCH AND DEVELOPMENT EXPENDITURE IN EUROPEAN UNION COUNTRIES
}

\author{
Lubica Hurbánková ${ }^{1}$
}

DOI: https://doi.org/10.31410/ITEMA.2020.137

\begin{abstract}
Paper deals with the analysis of research and development expenditure. Expenditure per capita in European Union countries in years 2009 - 2018 and total research and development expenditure in million Euro are analyzed. The aim of the paper is to find out in which countries expenditure per capita increased the most during the observed period and in which it decreased, what was the average annual growth rate of this indicator. Contribution method will help to analyze how the total research and development expenditure in 27 European Union countries has changed, what was the share of each country in this expenditure, which countries contributed the most to this change and which the least. Research and development expenditure per capita increased average annually between 2009 and 2018 in all analyzed countries, except Luxembourg and Finland, where it decreased. The highest average annual growth was recorded in Poland (12.48\%), Latvia (10.50\%), Slovakia (10.47\%) and Bulgaria (10.38\%). Total research and development expenditure increased in 2018 compared to 2009 by $41.65 \%$, Germany $(18.11 \%)$ and France (4.29\%) contributed the most to this increase.
\end{abstract}

Keywords: Research and development expenditure, European union countries, Contribution method.

\section{INTRODUCTION}

$\mathbf{R}$

esearch and development expenditure is an indicator, which includes expenditure on research and development by business enterprises, higher education institutions, government and private non-profit organizations (Eurostat, 2020).

Research and development expenditure comprise total amount of expenditures spent in organization on research and development activities, i.e. they are internal expenditures. Expenditures spent out of the organization include only those serving for support to the internal research and development (e.g. purchase of equipment for R\&D institutions). Depreciation of buildings, machines and equipment is excluded from the statistical survey of internal expenditures on research and development (Štatistický úrad Slovenskej republiky, 2019).

Research and development expenditure is associated directly with the research and development of a company's goods or services and any intellectual property generated in the process. They are direct expenditures relating to a company's efforts to develop, design, and enhance its products, services, technologies, or processes. The industrial, technological, health care, and pharmaceutical sectors typically incur the highest degree of R\&D expenses (Investopedia, 2020). 
The aim of the paper is to find out in which countries in the years 2009 - 2018 research and development expenditure per inhabitant increased the most and in which decreased, what was the average annual growth rate of this indicator. Next, we will analyze how the total research and development expenditure in 27 European Union countries has changed, what was the share of each country in this expenditure, which countries contributed the most to this change and which the least. We will use contribution method for this analysis.

\section{USING METHOD}

To find out how the analyzed indicator developed, we use the characteristics of time series basic index and average growth rate (see Pacáková et al., 2009).

As our goal is to find out how individual countries have contributed to the total change in research and development expenditure, we will use contribution method.

Contribution method is used for the analysis of additive indicator $Y$, which arise from the sum of individual components:

$$
Y=\sum_{i=1}^{n} y_{i}
$$

where: $Y$ is additive indicator, $y_{i}$ are individual components.

The procedure of this method is as follows (Hurbánková, Sivašová, 2018):

We calculate the relative increase of additive indicator, which expresses how the given indicator has changed:

$$
k_{d t}=\frac{Y_{t}-Y_{t-1}}{Y_{t-1}}=\frac{d(Y)}{Y_{t-1}}=\left(k_{Y}-1\right)
$$

We calculate the relative increases of the individual components, which express how the individual components developed:

$$
k_{d t}=\frac{y_{t}^{i}-y_{t-1}^{i}}{y_{t-1}^{i}}=\frac{d(y)}{y_{t-1}^{i}}=\left(k_{y}^{i}-1\right)
$$

We determine the structural numbers that express the share of individual components in additive indicator. We calculate the structural numbers in the period $t$ - 1 , assuming that the analogous share of the component on the additive indicator is maintained during the continuous development of the additive indicator:

$$
s_{t-1}^{i}=\frac{y_{t-1}^{i}}{Y_{t-1}}
$$

We calculate the contribution to which $i$-th component contributed to the relative increase of the additive indicator:

$$
\left(\frac{y_{t}^{i}-y_{t-1}^{i}}{y_{t-1}^{i}}\right) * \frac{y_{t-1}^{i}}{Y_{t-1}}=\left(k_{y}^{i}-1\right) * s_{t-1}^{i}
$$

The contribution of each additive component is equal to multiply of its relative increase and the share of this component in the additive indicator in the previous period. 
The relative increase of the additive indicator is equal to the sum of the relative contributions of the individual components (Hindls, Hronová, 1997):

$$
\sum_{i=1}^{n}\left(\frac{y_{t}^{i}-y_{t-1}^{i}}{y_{t-1}^{i}}\right) * \frac{y_{t-1}^{i}}{Y_{t-1}}=\frac{1}{Y_{t-1}} \sum_{i=1}^{n}\left(y_{t}^{i}-y_{t-1}^{i}\right)=\frac{1}{Y_{t-1}}\left(\sum_{i=1}^{n} y_{t}^{i}-\sum_{i=1}^{n} y_{t-1}^{i}\right)=\frac{Y_{t}-Y_{t-1}}{Y_{t-1}}
$$

\section{ANALYSIS OF RESEARCH AND DEVELOPMENT EXPENDITURE IN EUROPEAN UNION COUNTRIES}

Table 1 shows data on research and development expenditure per inhabitant in European Union countries in years 2009 - 2018 in Euro. The trend of this indicator in 2018 compared to 2009 and the average annual growth rate are calculated.

Table 1. Research and development expenditure per inhabitant in European Union countries in 2009 - 2018 in Euro, its trend in 2018 compared to 2009 and average annual growth rate

\begin{tabular}{|c|c|c|c|c|c|c|c|c|c|c|c|c|}
\hline GEO/TIME & 2009 & 2010 & 2011 & 2012 & 2013 & 2014 & 2015 & 2016 & 2017 & 2018 & \begin{tabular}{c|}
2018 \\
$/ 2009$
\end{tabular} & $\begin{array}{c}\text { Average } \\
\text { annual } \\
\text { growth } \\
\text { rate }\end{array}$ \\
\hline EU 27 & 473,7 & 490,8 & 519,0 & 537,2 & 543,9 & 558,2 & 582,7 & 594,9 & 629,2 & 661,9 & 1,3973 & 1,0379 \\
\hline Belgium & 644,0 & 690,7 & 742,8 & 795,3 & 822,1 & 854,3 & 900,4 & 959,5 & 1045,5 & 1115 & 1,7314 & 1,0629 \\
\hline Bulgaria & 24,7 & 29,0 & 29,8 & 34,6 & 36,6 & 46,9 & 60,4 & 52,5 & 54,7 & 60,1 & 2,4332 & 1,1038 \\
\hline Czechia & 184,6 & 200,3 & 243,4 & 273,9 & 285 & 294,0 & 308,4 & 280,8 & 324,5 & 377,6 & 2,0455 & 1,0828 \\
\hline Denmark & 1282 & 1281,6 & 1312,7 & 1360,0 & 1371,8 & 1376,2 & 1473,7 & 1534,2 & 1551,4 & 1580,9 & 1,2332 & 1,0236 \\
\hline Germany & 818,0 & 855,9 & 942,0 & 984,8 & 990,1 & 1043,1 & 1093,4 & 1121,7 & 1206,4 & 1266,3 & 1,5480 & 1,0498 \\
\hline Estonia & 147,8 & 174,6 & 289,1 & 287,3 & 247 & 217,9 & 230,3 & 205,4 & 231,3 & 277,2 & 1,8755 & 1,0724 \\
\hline Ireland & 605,0 & 586,8 & 583,2 & 595,7 & 610,3 & 639,8 & 664,6 & 671,8 & 768,2 & 769,5 & 1,2719 & 1,0271 \\
\hline Greece & 133,9 & 121,6 & 125,1 & 120,7 & 133,2 & 136,2 & 156,9 & 162,7 & 189,3 & 202,5 & 1,5123 & 1,0470 \\
\hline Spain & 315,4 & 313,8 & 303,9 & 286,0 & 278,5 & 275,6 & 283,6 & 285,5 & 302,2 & 320,3 & 1,0155 & 1,0017 \\
\hline France & 665,7 & 672,3 & 694,3 & 712,6 & 722 & 724,2 & 749,9 & 745,1 & 757,7 & 773,6 & 1,1621 & 1,0168 \\
\hline Croatia & 88,3 & 77,9 & 78,4 & 77,2 & 83,2 & 80,0 & 88,7 & 96,0 & 101,9 & 122,2 & 1,3839 & 1,0368 \\
\hline Italy & 325,6 & 331,6 & 333,7 & 345,2 & 351,6 & 358,3 & 364,5 & 382,0 & 392,7 & 406,4 & 1,2482 & 1,0249 \\
\hline Cyprus & 104,1 & 105,2 & 107,0 & 99,0 & 101,0 & 104,3 & 100,7 & 116,5 & 128,9 & 134,0 & 1,2872 & 1,0285 \\
\hline Latvia & 39,2 & 51,2 & 67,8 & 71,7 & 69,1 & 81,3 & 76,6 & 56,1 & 70,7 & 96,3 & 2,4566 & 1,1050 \\
\hline Lithuania & 70,2 & 69,9 & 92,6 & 99,3 & 111,9 & 128 & 133,4 & 113,4 & 133,0 & 151,8 & 2,1624 & 1,0895 \\
\hline Luxembourg & 1256,9 & 1202,4 & 1233,6 & 1069,6 & 1127,9 & 1146,7 & 1204,4 & 1235,8 & 1220,1 & 1208,3 & 0,9613 & 0,9956 \\
\hline Hungary & 106,4 & 112,4 & 120,6 & 126,6 & 142,8 & 144,7 & 153,3 & 139,5 & 170,8 & 209,8 & 1,9718 & 1,0784 \\
\hline Malta & 77,3 & 96,7 & 111 & 141,9 & 139,8 & 141,0 & 162,6 & 130,3 & 143,2 & 148,8 & 1,9250 & 1,0755 \\
\hline Netherlands & 631,3 & 657,1 & 734,6 & 747,9 & 759,6 & 788,4 & 810,4 & 833,0 & 857,0 & 974,8 & 1,5441 & 1,0495 \\
\hline Austria & 897,4 & 965,9 & 988,2 & 1104,6 & 1132,4 & 1207,7 & 1223,0 & 1279,9 & 1286,9 & 1388,1 & 1,5468 & 1,0497 \\
\hline Poland & 55,0 & 68,6 & 74,5 & 90,1 & 90,3 & 101,6 & 113,6 & 108,3 & 127,3 & 158,5 & 2,8818 & 1,1248 \\
\hline Portugal & 262,4 & 260,8 & 242,7 & 220,1 & 215,4 & 214,1 & 215,4 & 231,0 & 250,7 & 269,1 & 1,0255 & 1,0028 \\
\hline Romania & 27,2 & 28,2 & 32,5 & 32,1 & 27,9 & 28,8 & 39,4 & 41,4 & 48,1 & 52,5 & 1,9301 & 1,0758 \\
\hline Slovenia & 323,2 & 364,4 & 436,2 & 451,6 & 454,1 & 431,9 & 413,5 & 393,4 & 388,4 & 431,8 & 1,3360 & 1,0327 \\
\hline Slovakia & 56,3 & 77,2 & 86,9 & 108,3 & 112,9 & 123,6 & 171,0 & 118,1 & 137,8 & 138,0 & 2,4512 & 1,1047 \\
\hline Finland & 1274,1 & 1302,7 & 1332,7 & 1264,9 & 1231,7 & 1194,6 & 1109,5 & 1080,0 & 1121,7 & 1167,7 & 0,9165 & 0,9904 \\
\hline Sweden & 1154,1 & 1270,8 & 1397,4 & 1464,9 & 1507,6 & 1411,3 & 1504,3 & 1537,0 & 1615,0 & 1544,6 & 1,3384 & 1,0329 \\
\hline
\end{tabular}

Source: Eurostat, 2020 and own calculations 
As can be seen from Table 1, the highest research and development expenditure (more than $1,000 €$ per inhabitant) was in Denmark (1,580.9€ per capita in 2018), Sweden, Finland and Luxembourg throughout the analyzed period. The lowest was in Bulgaria (only 24.7 Euro per inhabitant in 2009), Romania, Latvia, Slovakia, Poland, Lithuania and Malta. In 2018, compared to 2009, expenditure increased in all countries except Luxembourg and Finland, where it decreased - in Luxembourg by $3.87 \%$, which represents an average annual decrease of $0.44 \%$ and in Finland it decreased by $8.35 \%$, on average by $0.96 \%$ per year. This indicator grew the most in Poland in 2018 compared to 2009 by $188.18 \%$, which is an average annual increase of $12.48 \%$. In Slovakia, the third highest increase was recorded by $145.12 \%$, which is an average annual increase of $10.47 \%$.

In order to be able to calculate how countries have contributed to the total change in research and development expenditure, we need to have an absolute indicator. Therefore, we chose the indicator of total research and development expenditure, not per inhabitant. Input data and calculation using contribution method are shown in Table 2.

Table 2. Application of contribution method on research and development expenditure in European Union countries in 2009 and 2018

\begin{tabular}{|l|r|r|r|r|r|}
\hline \multicolumn{1}{|c|}{ GEO/TIME } & \multicolumn{1}{|c|}{2009} & \multicolumn{1}{c|}{2018} & $\begin{array}{l}\text { Relative } \\
\text { increase }\end{array}$ & $\begin{array}{c}\text { Structural } \\
\text { number }\end{array}$ & \multicolumn{1}{c|}{ Contribution } \\
\hline Belgium & 6924,591 & 12709,638 & 0,8354 & 0,0332 & 0,0278 \\
\hline Bulgaria & 184,610 & 423,818 & 1,2957 & 0,0009 & 0,0011 \\
\hline Czechia & 1924,518 & 4006,462 & 1,0818 & 0,0092 & 0,0100 \\
\hline Denmark & 7065,873 & 9139,430 & 0,2935 & 0,0339 & 0,0099 \\
\hline Germany & 67078,121 & 104836,000 & 0,5629 & 0,3218 & 0,1811 \\
\hline Estonia & 197,393 & 365,650 & 0,8524 & 0,0009 & 0,0008 \\
\hline Ireland & 2735,556 & 3716,800 & 0,3587 & 0,0131 & 0,0047 \\
\hline Greece & 1485,940 & 2174,670 & 0,4635 & 0,0071 & 0,0033 \\
\hline Spain & 14581,676 & 14946,000 & 0,0250 & 0,0700 & 0,0017 \\
\hline France & 42834,917 & 51768,559 & 0,2086 & 0,2055 & 0,0429 \\
\hline Croatia & 380,677 & 501,756 & 0,3181 & 0,0018 & 0,0006 \\
\hline Italy & 19209,000 & 24581,681 & 0,2797 & 0,0921 & 0,0258 \\
\hline Cyprus & 82,988 & 115,800 & 0,3954 & 0,0004 & 0,0002 \\
\hline Latvia & 84,882 & 186,200 & 1,1936 & 0,0004 & 0,0005 \\
\hline Lithuania & 223,471 & 426,306 & 0,9077 & 0,0011 & 0,0010 \\
\hline Luxembourg & 620,280 & 727,400 & 0,1727 & 0,0030 & 0,0005 \\
\hline Hungary & 1067,166 & 2051,375 & 0,9223 & 0,0051 & 0,0047 \\
\hline Malta & 31,761 & 70,792 & 1,2289 & 0,0002 & 0,0002 \\
\hline Netherlands & 10408,000 & 16748,200 & 0,6092 & 0,0499 & 0,0304 \\
\hline Austria & 7479,745 & 12246,010 & 0,6372 & 0,0359 & 0,0229 \\
\hline Poland & 2095,827 & 6018,489 & 1,8717 & 0,0101 & 0,0188 \\
\hline Portugal & 2771,600 & 2769,072 & $-0,0009$ & 0,0133 & 0,0000 \\
\hline Romania & 555,887 & 1024,770 & 0,8435 & 0,0027 & 0,0022 \\
\hline Slovenia & 656,882 & 892,399 & 0,3585 & 0,0032 & 0,0011 \\
\hline Slovakia & 302,994 & 750,947 & 1,4784 & 0,0015 & 0,0021 \\
\hline Finland & 6786,472 & 6437,900 & $-0,0514$ & 0,0326 & $-0,0017$ \\
\hline Sweden & 15626 & 15631,342 & 0,4632 & 0,0512 & 0,0237 \\
\hline EU 27 & 453,653 & 295267,466 & 0,4165 & 1,0000 & 0,4165 \\
\hline & & & & \\
\hline
\end{tabular}

Source: Eurostat, 2020 and own calculations 
From Table 2 we found out that total research and development expenditure in EU-27 increased by $41.65 \%$ in 2018 compared to 2009 , with the largest increase in Poland by $187.17 \%$ (similar to research and development expenditure per inhabitant) and in Slovakia by $147.84 \%$. They decreased only in Portugal (by $0.09 \%$ ) and Finland (by 5.14\%). Germany (32.18\%) and France $(20.55 \%)$ had the highest share in total expenditure in 2009. Germany $(18.11 \%)$ and France (4.29\%) contributed the most to the $41.65 \%$ increase in total expenditure. In 2009, Slovakia had only a $0.15 \%$ share in this indicator for all EU-27 countries and contributed only $0.21 \%$ to the increase.

\section{CONCLUSION}

From the realized analysis we can draw the following conclusions:

$>$ The highest research and development expenditure was in Denmark in $2018(1,580.9 €$ per capita). The lowest was in Bulgaria (only 24.7 Euro per inhabitant in 2009).

$>$ In 2018, compared to 2009, expenditure increased in all countries except Luxembourg and Finland, where it decreased - in Luxembourg by 3.87\% (average annual decrease of $0.44 \%$ ) and in Finland by $8.35 \%$ (on average by $0.96 \%$ per year). This indicator grew the most in Poland in 2018 compared to 2009 by $188.18 \%$ (average annual increase of $12.48 \%$ ). In Slovakia, the third highest increase was recorded by $145.12 \%$ (average annual increase of $10.47 \%$ ).

$>$ Total research and development expenditure in EU-27 increased by $41.65 \%$ in 2018 compared to 2009, with the largest increase in Poland by $187.17 \%$ and in Slovakia by $147.84 \%$. They decreased only in Portugal (by $0.09 \%$ ) and Finland (by $5.14 \%$ ). Germany $(32.18 \%)$ and France $(20.55 \%)$ had the highest share in total expenditure in 2009. Germany $(18.11 \%)$ and France $(4.29 \%)$ contributed the most to the $41.65 \%$ increase in total expenditure. Slovakia contributed only $0.21 \%$ to the increase.

\section{ACKNOWLEDGMENT}

This research was supported by the Grant Agency of Slovak Republic [KEGA grant number O07EU-4/2020 Interactive and interdisciplinary teaching of Services and Tourism Innovation subjects using information technology].

\section{REFERENCES}

Eurostat

(2020)

https://appsso.eurostat.ec.europa.eu/nui/show.do?dataset=rd_e_gerdtot\&lang=en (cited 22.9.2020).

Eurostat (2020) https://appsso.eurostat.ec.europa.eu/nui/submitViewTableAction.do (cited 22.9.2020).

Eurostat

https://ec.europa.eu/eurostat/statisticsexplained/index.php?title=Glossary:Gross_domestic_expenditure_on_R_\%26_D_(GER D) (cited 22.9.2020).

Hindls, R. \& Hronová, S. (1997). Vývoj domácího produktu z hlediska přispění jednotlivých faktorú. Politická ekonomie, 1997 (5), pp. 699-707.

Hurbánková, L. \& Sivašová, D. (2018). Hospodárska štatistika I. Bratislava: Vydavatel'stvo EKONÓM. pp. 140.

Investopedia (2020) https://www.investopedia.com/terms/r/research-and-developmentexpenses.asp (cited 22.9.2020). 
Pacáková, V. et al. (2009). Štatistické metódy pre ekonómov. Bratislava: Iura Edition. pp 405.

Štatistický úrad Slovenskej republiky (2019). Štatistická ročenka Slovenskej republiky 2019. Bratislava: Veda. 